\title{
The Shifting Hydrology and Water Resources under the Changing Climate \\ Mingxin Guo*
}

Department of Agriculture and Natural Resources, Delaware State University, Dover, DE 19901, USA

The fifth assessment report recently released from the Intergovernmental Panel on Climate Change (IPCC) states that "Warming of the climate system is unequivocal, and since the 1950s, many of the observed changes are unprecedented over decades to millennia. The atmosphere and ocean have warmed, the amounts of snow and ice have diminished, sea level has risen, and the concentrations of greenhouse gases have increased" [1]. Indeed, the atmospheric $\mathrm{CO}_{2}$ concentration has been elevated from the $280 \mathrm{ppm}$ preindustrial level to the present $400 \mathrm{ppm}$ mainly due to fossil fuel consumption [2], as accompanied with the global surface average temperature increase by $1.5^{\circ} \mathrm{F}$ (to $58.3^{\circ} \mathrm{F}$ in 2012 ) during the same period [3]. The Earth's surface has been successively warmer in each of the past three decades, showing an increasing temperature higher than any preceding decade since 1850 [1].Therefore, scientists are mostly confident (i.e., $>95 \%$ probability) that global warming is occurring and humans are responsible for at least half of the temperature increase in the last 50 years [1]. The Earth's climate system has been changing as a result of the ongoing increases in the atmospheric $\mathrm{CO}_{2}$ concentration and the global average surface temperature. Other climate change signs include the experiencing decreases of the Arctic sea ice, the Northern Hemisphere snowfall, and the global glacier coverage and the experiencing increases in sea surface temperature, ocean heat content, air humidity, and frequency and severity of extreme weathers [4]. Water is a critical component of the Earth's climate system and influences climate through its circulating movement in the hydrosphere. Climate change, in turn, affects various hydrological processes and alters the overall hydrological cycle, leading to noticeable variations in water evapotranspiration, precipitation pattern (i.e., amount, timing, form, and intensity), water flow in watersheds, water distribution, drought and flood incidence, and water quality as well as aquatic environments [5]. These variations express climate change, further climate change, and will substantially impact water resources management, civil water supply, and public health and safety.

The total amount of water on the Earth is estimated at 1386 million $\mathrm{km}^{3}$ (liquid volume at $4^{\circ} \mathrm{C}$ ), of which $98.24 \%$ is in liquid, $1.76 \%$ in solid and $0.001 \%\left(12,900 \mathrm{~km}^{3}\right)$ in vapor [6]. The water transforms between the three phases as a function of temperature and humidity and circulates between ocean, atmosphere, and land via evaporation, precipitation, stream flow, and other hydrological processes [7]. Although freshwater accounts for $2.55 \%$ of the total water, $70 \%$ of the freshwater is in permanent ice (e.g., ice in the Antarctic and the Arctic) and 18\% is stored in deep ground, unavailable for human use [7]. Lakes and rivers contain $93,113 \mathrm{~km}^{3}(0.0067 \%$ of the total water $)$ of liquid freshwater. The annual precipitation on land is $108,000 \mathrm{~km}^{3}$, two thirds returning to the atmosphere via evapotranspiration and one third ultimately available for people and life as a renewable resource $(0.0026 \%$ of the total water) [6].

The water cycle illustrates the delicate balance among the various hydrological processes evapotranspiration, precipitation, and all steps in between. As the global average temperature increases, water evaporation and plant transpiration are promoted, more water entering into the atmosphere in vapor. Increased evapotranspiration may cause some areas (e.g., at lower latitudes) "drier." Meanwhile, the water holding capacity of the atmosphere is increased at a higher temperature [8]. The excess water eventually falling to the ground in precipitation may result in certain regions (e.g., at higher latitudes) "wetter conditions."Overall, a changing climate leads to adjustments in timing, intensity, and duration of precipitation over geographic regions, altering the hydrology of impacted watersheds and water resource distribution. Globally it is projected that the annual average river runoff will increase by $10-40 \%$ at high latitudes and in some wet tropical areas by 2050, but will decrease by $10-30 \%$ in some dry regions at mid-latitudes and in the subtropics [9]. Monitoring data show that the amount of precipitation during the most intense $1 \%$ of storms has increased by nearly $20 \%$ in the U.S. over the past 50 years [8]. During the same period the West of the U.S. has experienced less rain and more severe droughts (Figure 1).Furthermore, the elevated temperature has reduced the snowfall in the winter time and made snow to melt earlier in the year, altering the stream flow timing of snowmeltfeeding rivers [8]. Climate models forecast that as temperature rises, the Colorado River Basin will face increasing water demands and reservoir evaporation losses but decreasing reservoir inflows, leading to substantial degradation of the basin ecosystem [10]. Declining snow

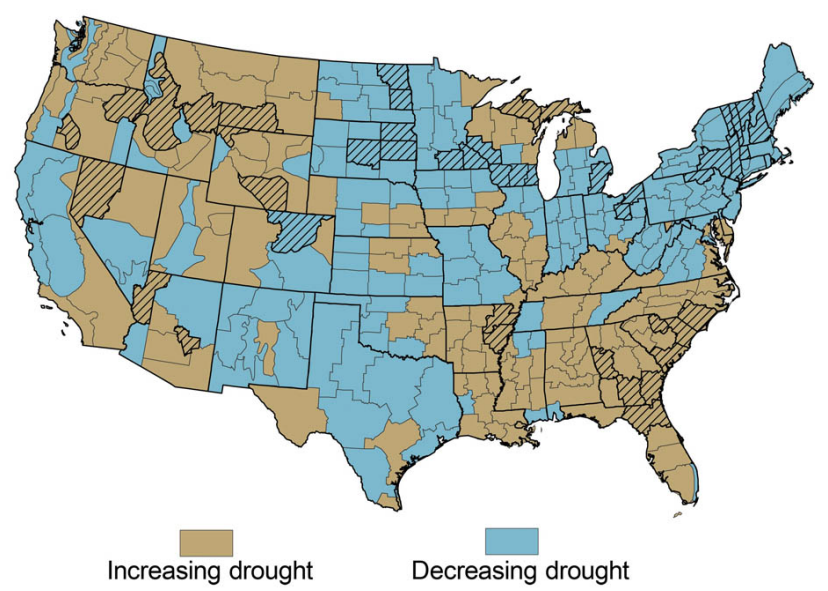

Figure 1: Observed drought trends in the U.S., with hatching indicating a significant trend [13].

${ }^{*}$ Corresponding author: Mingxin Guo, Department of Agriculture and Natural Resources, Delaware State University, Dover, DE 19901, USA, Tel: 1 (302) 857 6479; Fax - 1 302- 857-6455; E-mail: mguo@desu.edu

Received January 15, 2014; Accepted January 20, 2014; Published January 24 2014

Citation: Guo M (2014) The Shifting Hydrology and Water Resources under the Changing Climate. Hydrol Current Res 5: e116. doi:10.4172/2157-7587.1000e116

Copyright: @ 2014 Guo M. This is an open-access article distributed under the terms of the Creative Commons Attribution License, which permits unrestricted use, distribution, and reproduction in any medium, provided the original author and source are credited. 
Citation: Guo M (2014) The Shifting Hydrology and Water Resources under the Changing Climate. Hydrol Current Res 5: e116. doi:10.4172/2157$7587.1000 \mathrm{e} 116$

packs in British Columbia, Canada and the impacts on aquifer recharge and community water supply have been observed [11]. Enhanced melting and elongated melt season of mountain glaciers are evidenced in Alaska, Andes, and Alps, resulting in increased river runoff and discharge peaks and even crustal uplift $[9,12]$.

Additional liquid water from melting glaciers and ice caps and thermal expansion of water as temperature increases have been causing the sea level to rise. From 1880 to 2011, the global average absolute sea level rose approximately $23 \mathrm{~cm}$; and the rising rate in the last decade $(\sim 0.30 \mathrm{~cm} / \mathrm{yr})$ is nearly doubles that of the last century [14]. The rising sea level is altering coastal ecosystems, transforming marshes and other wetlands into open water and invading freshwater systems with salt water. It is subjecting low-lying coastal areas to increased flooding and erosion and making coastal infrastructure more vulnerable to damage from storms [14].

Climate change is having a compound impact on the quality and availability of water resources. As regional precipitation and runoff change in timing, intensity, and amount, water supply and water-related human activities will be greatly influenced. Worldwide in general, drought will be widespread and flooding be more frequent [9]. Storm surges and saltwater intrusion threaten water supplies in coastal areas and on small ocean islands. More frequent and severe storms increase the amount and intensity of runoff into rivers and lakes, carrying more sediment, nutrients, animal waste, trash, and other pollutants into water supplies. This is particularly true for the U.S. Northeast and Midwest regions experiencing increased precipitation (Figure 1). The increasing water temperatures can stimulate algal blooms and bacteria incidences in water bodies. Semi-arid and arid areas (e.g., the Mediterranean, southern Africa, and northeastern Brazil) are particularly vulnerable to climate change-incurred impacts on water resources [9].

Climate change influences water demand, water supply, and related economic activities. In a warmer environment, plants, animals, and humans consume more water to maintain their physiological function and health. Livestock and managed plants are susceptible to drought stress. The requirement for water to raise domestic animals and grow agricultural crops will increase as the global temperature rises. Even winter sport activities such as snow skiing, ice skating, and ice fishing will be limited due to reduced snow and ice availability. Moreover, changes in precipitation, sea level, and temperature may affect the quality of water bodies such as beaches, lakes, and streams for swimming, fishing, canoeing, and other recreational activities. In addition, the habitats of aquatic organisms may be altered as water becomes warmer, encouraging non-native species to invade previously coldwater bodies and forcing coldwater species (e.g., trout) to migrate [15].

In short, climate change has compound impacts on hydrology and water resources. The impacts vary with geographic regions and challenge all-level water resource management. More research and monitoring efforts are necessary to understand, predict, and adapt the impacts.

\section{References}

1. IPCC (2013) Climate Change 2013-The Physical Science Basis. Intergovernmental Panel on Climate Change: Geneva, Switzerland.

2. NOAA (2013) Carbon dioxide at NOAA's Mauna Loa Observatory reaches new milestone: Tops 400 ppm. National Oceanic and Atmospheric Administration: Washington, DC

3. NASA (2013) NASA finds 2012 sustained long-term climate warming trend. Available at National Aeronautics and Space Administration: Washington, DC.

4. NOAA (2010) Ten signs of a warming world. National Oceanic and Atmospheric Administration: Washington, DC.

5. USEPA (2013) Climate change and water. United States Environmental Protection Agency: Washington DC.

6. Gleick PH (1996) Water resources. In SH Schneider (ed) Encyclopedia of Climate and Weather, Oxford University Press: New York, NY 2: 817-823.

7. Viessman W, Lewi GL (2003) Introduction to Hydrology. ( $5^{\text {th }}$ edn), Prentice Hall: Upper Saddle River, NJ, USA.

8. Karl TR, Melillo JM, Peterson TC (2009) Global Climate Change Impacts in the United States. Cambridge University Press, New York, NY, USA.

9. IPCC (2008) Linking climate change and water resources: impacts and responses. Intergovernmental Panel on Climate Change: Geneva, Switzerland.

10. Christensen NS, Wood AW, Voisin N, Lettenmaier DP, Palmer RN (2010) The effects of climate change on the hydrology and water resources of the Colorado River Basin. Climate Change 62: 337-363.

11. BCMOE (2007) Environmental trends in British Columbia: 2007. Ministry of Environment: Victoria, B.C, Canada.

12. Larsen CF, Motyka RJ, Freymueller JT, Echelmeyer KA, Ivins ER (2005) Rapid viscoelastic uplift in southeast Alaska caused by post-little ice age glacial retreat. Earth and Planetary Science Letters 237: 548-560.

13. USGCRP (2009) Global Climate Change Impacts in the United States. Cambridge University Press, New York, NY, USA.

14. EPA (2013) Climate change indicators in the United States: sea level. United States Environmental Protection Agency: Washington DC, USA.

15. EPA (2013) Climate change and water resources. United States Environmental Protection Agency: Washington DC, USA. 